\title{
The Use of Online Materials for Independent Development of English Competency
}

\author{
Asry Ayu Diliyanti* \\ Postgraduate English Department \\ Universitas Mataram \\ Mataram, Indonesia \\ asryayu84@gmail.com
}

\author{
Mahyuni Mahyuni \\ Postgraduate English Department \\ Universitas Mataram \\ Mataram, Indonesia \\ mahyuni@unram.ac.id
}

\author{
Muhammad Amin \\ Postgraduate English Department \\ Universitas Mataram \\ Mataram, Indonesia \\ aminmuhammad@unram.ac.id
}

\begin{abstract}
This paper examines the use of online materials that students can explore independently to improve their English competency. This paper focuses on how those online materials that students can find globally help them to communicate fluently in English. The study is qualitative in nature as it uses descriptive survey which was applied to obtain responses from the sample size of 50 students selected randomly from both IPA and IPS majors. The data were collected by using questionnaire and interviews to 3 students from each sample class focusing on (a) the types of online materials that the students used, (b) the procedures in which they have independently used them, and (c) the extent to which such use has impacted on their English competency. The data were analyzed using the following procedure: (a) identifying and classifying the types of materials and methods of use, and (b) statically determining the impact of such use. The study found that all participants use online materials of interest to them, and there are sufficient materials according to the student needs. However, the methods of use were still traditional and mechanical in which examples of materials were mechanically copied for the sources without sufficient adaptation to the nature of tasks that the teachers had requested. The study also found that the use of online materials has significantly helped students to improve their fluency and competency in English. This study also explicates how students find it much easier to develop fluency and competency through independent works compared to teacher-supervised works. In addition, the study findings are expected to give another perspective among teachers in this 4.0 era in which development independent learning prepares students to be lifelong learners.
\end{abstract}

Keywords - online materials, independent development, English competency, fluency

\section{INTRODUCTION}

Teachers have been both the centers of learning and the sources of knowledge for the students. Without their presence there will be no learning processes among the students. These types of practices have been going on for decades and have not significantly changed at all. However, nowadays, there is a new paradigm, shifting from teacher-centered learning to student-centered learning. In Indonesia, this has started since the minister of education created the 2013 Curriculum (K-13) and encouraged the schools to apply it. The students are expected to be the centers of learning processes, in which the learning processes will be held with or without the presence of teachers. Student-centered learning provides students with opportunities to control their own learning. It also requires students to take more responsibility on their own learning by being more actively involved in the learning processes rather than being passive in receiving information from teachers as they have traditionally done in decades [1]. The roles that teachers could play in the students-centered learning have now become more like facilitators, guides, and supporters that facilitate students in learning. By the same token, the students are no longer passively absorbing knowledge and information. Instead, as Tärnvik has explicated, the students should know what and how to learn and in so doing the teachers facilitate them [2].

This brings us to the concept of autonomous learning. According to Vansteenkiste, autonomous learning is students' self-directed learning [3]. Autonomy here implies that the students learn the material independently, and they set appropriate learning target to take charge of their own learning. Students are the center of the educational enterprise, and as a center of learning students have a responsibility to study independently in order to improve both cognitive and affective aspects. By improving those aspects, the students have supply themselves with learning resources which can help them to extend their competency in English. Students can be the experts for themselves as long as they got proper material to learn. Commonly, the obligation to provide decent material to support students in learning independently is the responsibility of the government, the society, and the teachers. Cornelius and Gordon found that student-centered learning was facilitated by flexibility in content delivery and study strategies, and the individual student learning needs were accommodated [4]. Traditionally decent materials that students use as sources to learn are textbooks, student's worksheets, and some from newspapers. In fact, it is quite unlikely for the government, society, or teacher to provide those materials for every single students of this country. Due to the lack of financial resources and the difficulty in distributing it, making that traditional resources are arduous and almost impossible to be done.

One of the characteristics as an independent learner, students need to have sources that easy to access and carry out everywhere to facilitate them whenever they want to use it. Since neither the government nor teacher can provide it, the easiest way to students to obtain those learning resources are through online materials. In this era, well known as an industrial 4.0 era, where internet and technology are extensively used in our society, people can access something online as well as online materials more easily. The term material in language teaching and learning refers to everything used to help teaching language learners [5]. Being online means that participant is connected to such a system called internet that lead the participant to access anything globally. Online material is everything that students' access from the internet which help to improve their competence in learning English. As 
long as students' devices are connected to the internet, they are able to access tons of online platform which contain millions of materials which students need. Some of those online platforms which can be accessed freely are YouTube and Google. From those platforms, students can gather millions of learning materials which they can access every single time they want to.

Learning materials have necessarily been essential parts to the development of students' competence in learning English. A competence of student is reflected by their learning result as well as their knowledge. According to Chomsky, competence is the ideal language system that enables speakers to produce and understand an infinite number of sentences in their language, and to distinguish grammatical sentences from ungrammatical sentences. Technical term competence refers to the ability of the idealized speaker-hearer to associate sounds and meanings strictly in accordance with the rules of the language [6]. The grammar of a language, as a model for idealized competence, establishes a certain relation between sound and meaning [7]. Competence has strong relation to ability to speak fluently. That the main function of a language is as a tool to communicate, to share ideas and thoughts and to express feelings makes speaking skill become so important. In addition, native speakers of English are able to recognize English learners' competence through fluency of their speaking. The more students speak English fluently the more they are confident with their English competency. If students are confident with their competency of English, their intrinsic motivation will increase and this will trigger them to learn more.

Students construct new knowledge based upon their prior experience and personal interpretation of the world rather than passive reception of information [8]. Leaning independently using online materials will give students experiences and strategies to learning. Moreover, materials that are available in online platform are countless and varied, students can just pick which materials they need either from YouTube or Google. This surely helps students to improve more, as we know that learning inside the class has limited time and facility. Therefore, independent learning using online materials can be a solution for students to fluent their English. So far, there has been no such research on what materials are available online that can support students in learning independently to develop their ability to speak English. Thus, this study will be so helpful for both teachers and students to blend in this Industry 4.0 era and make great improvement in educational field.

\section{METHOD}

This research was conducted using descriptive qualitative method. This method was used to describe the use of online materials in independent development of English competency. The result of this research describes the functions of online materials used independently by students and the extent to which it helps students to improve their fluency in English. Qualitative research as a form of social enquiry that focuses on the way people interpret and make sense of their experience and the world in which they live [9].
The population in this study are the eleventh-grade students of SMA 2 Mataram. There are two majors for the eleventh-grade students namely science and social majors. In the science major, there are eight classes and each class consists of 30-40 students. Meanwhile, there are five classes in social major which has 25-37 students per class. These students were taken as the population since they are English learners and they also familiar with the term of online materials and online platform. The random sampling technique was used in which some students were taken randomly as a sample from each class of both science and social majors. Students were selected randomly from attendant list of their classes and 100 students were taken as sample in this study. The sample taken randomly to give an equal chance for all the students to participate in this study.

The data were collected through interview technique. According to Cohen, Manion \& Morison, interviewing is "a valuable method for exploring the construction and negotiation of meanings in a natural setting" [10]. Interview is particularly useful to gather deep information related to the topics of this study such as the usage of online materials, positive impacts of being independent learner, students' experience in accessing online materials, and students' fluency. Types of interview applied in this study is open-ended interview which means the students are allowed to elaborate their explanation. It gives chances to interviewees to speak in their own voice and express their own thoughts and feelings [11]. This type of interview is focused more on the participant's thoughts, feelings, experiences, knowledge, skills, ideas and preferences. Therefore, this technique is suitable to gather detail information to be analyzed as data of this study.

This study is focused on YouTube and Google as those the only online platforms to get online materials and surf the internet. One of the techniques to collect the data is to obtain the data from YouTube and Google directly since there are some information or data that cannot be obtained from any other resources. Therefore, browsing through those platforms was needed. Data analysis of this study started from looking for the variation of online materials which are available on online platforms. Second, identifying the data which can be used to improve fluency of students. Then, gauging students' competence in speaking skill through the interview.

\section{RESULTS AND DISCUSSION}

\section{A. The Internet Sources}

YouTube and Google provide million materials that can help students develop fluency in speaking skill. Using some key words such as, practice English speaking skill, English speaking conversation, English practice, fluency practice in English, and any other fluency or Englishspeaking skill aspects can be used as key words to find materials both in YouTube and Google. Online materials that are available for learning independently can be divided into two: written and audio-visual materials. Audio-visual materials are mostly available on YouTube. Meanwhile, the written materials are provided in millions on Google. 
TABLE I. MATERIALS TO IMPROVE SPEAKING FLUENCY ON THE INTERNET

\begin{tabular}{|l|l|l|}
\hline No. & Online Platform & Findings \\
\hline 1. & Google & 25.000 .000 \\
\hline 2. & YouTube & $39.000 .000++$ \\
\hline
\end{tabular}

The table indicates numbers of online materials that can be used to improve English speaking fluency which are available in YouTube and Google.

\section{B. Types of Materials}

The types of materials on the internet can be divided into one-way task and two-way task. From its form it can be divided into written material and audio-visual material. Table 2 shows that those type of materials are provided in huge numbers. It shows that online materials are varied and flexible to use since they supply what students need related to the practice of speaking.

TABLE II. TYPES OF MATERIALS BASED ON TYPES OF TASKS

\begin{tabular}{|l|l|l|}
\hline No. & Types of materials & Findings \\
\hline 1. & One-way task & 13.000 .000 \\
\hline 2. & Two-way task & 14.100 .000 \\
\hline
\end{tabular}

TABLE III. TYPES OF MATERIALS BASED ON FORM

\begin{tabular}{|l|l|l|}
\hline No. & Types of materials & Findings \\
\hline 1. & Written & $23.700 .000++$ \\
\hline 2. & Audio-visual & $\infty$ \\
\hline
\end{tabular}

\section{Interview findings}

Results of the interview will be discussed based on students' responses to the questions given. The responses of students become the data to be analyzed.

The interview results gotten from six interviewees are divided based on several categories as follow:

- Students' frequency in accessing online materials.

- Types of online materials which the students access to fulfill their needs.

- The extent to which online materials are helpful for students.

- Students' experience in using online materials.

- Students' preferences of materials (traditional or modern).

Students' frequently access materials from their advanced electronics, mainly from their smartphone. Since most of students' electronic devices are connected to internet, they can access and obtain the materials in any time more easily. Based on students' responses, the type of materials they search online is the material related to the topic they have been taught in class and the assignment they have got from their teacher. The type of online materials students highly choose are audio-visual material. Audio-visual materials are much more attractive for students' independent learning as they describe information in the interactive way and varied compared to that of written form, as shown at table 3. Students also stated that they rarely search online materials which represent their interests or hobbies. For some students, learning language through their favorite things is fun, in which they enjoy the process of independent learning. For instance, students learn accurate pronunciation using conversations video from YouTube. In general, it is found that on YouTube there are million conversations videos from a lot of people all over the world, as presented in table 1 . They can be used by the students to practice their pronunciation and learning new vocabulary. Students experienced exciting, pleasing, and handy when using online material independently to develop their English competence. Obviously, from those statements, it can be seen that students prefer modern materials which are online instead of the traditional one (from book), since they give much more convenient for students to establish their competence in learning language especially in their fluency in speaking. Furthermore, throughout the interview process, students' fluency in speaking English is assessed to ensure the extent to which online learning materials affect students' speaking performance. It is found from the interview that most of the students speak fluently when sharing their thoughts and experiences related to online materials that they use.

\section{CONCLUSION}

To sum up, analyses show that the quantity of online material is numerous and various, it can cover all students' needs. Students do not need to be confused with where and how to find learning resources to learn independently. At the time, they connect to internet, online materials are already in their hand. Nothing that is really difficult to access in this industrial 4.0 era involving learning materials.

\section{REFERENCES}

[1] K. M. Slunt and L. C. Giancarlo, "Student-centered learning: A comparison of two different methods of instruction," $J$. Chem. Educ., vol. 81, no. 7, p. 985, 2004

[2] A. Tärnvik, "Revival of the case method: a way to retain student-centred learning in a post-PBL era," Med. Teach., vol. 29, no. 1, pp. e32-e36, 2007.

[3] M. Vansteenkiste, "Self-determination theory: further insights in autonomy-supportive and controlling teaching styles," in International Conference on Motivation 'Cognition, Motivation and Effect', Lisbon, Portugal, 2004.

[4] S. Cornelius and C. Gordon, "Providing a flexible, learnercentred programme: Challenges for educators," Internet High. Educ., vol. 11, no. 1, pp. 33-41, 2008.

[5] B. Tomlinson, Materials development in language teaching. Cambridge University Press, 2011.

[6] N. Chomsky, Aspects of the Theory of Syntax, vol. 11. MIT press, 2014.

[7] N. Chomsky, Language and mind. New York: Harcourt, Brace \& World, 1968.

[8] J. Piaget, "Science of Education and the Psychology of the Child. New York: Viking. Project Based Learning." 1969.

[9] I. Holloway and S. Wheeler, Qualitative research in nursing. Wiley-Blackwell, 2002.

[10] L. Cohen, "Experiments, quasi-experiments, single-case research and meta-analysis (Cohen, L., Manion, L., \& Morrison, K. in Eds) Research methods in education.(6th eds.)." London: Routledge Falmer, 2007.

[11] H. Lune and B. L. Berg, Qualitative research methods for the social sciences. Pearson Higher Ed, 2016. 